老年症候群の適切な把握のためのもの忘れセンター予診票の作成に関する検討 一予診票の妥当性と信頼性および回答者による回答率の差異についての検証一

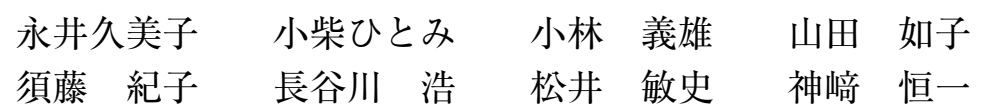

要 約 目的：加齢に伴い出現する老年症候群を適切に把握することは, 高齢者の診療にとって重要である. 今回我々はより具体的かつ正確に評価することを目的として予診票の改訂を行い, 妥当性および信頼性を検 討した. 方法：対象は杏林大学病院もの忘れセンター初診患者. 2011 年 10 月〜2012 年 7 月の初診患者 459 人には従前の質問形式による旧予診票を, 2012 年 8 月〜 12 月の初診患者 277 人には新予診票を診察前に渡 し, 患者本人もしくは家族その他の同伴者が記入の上, 老年症候群の有無を調査した. 新予診票の質問項目 は各種ガイドラインの診断基準を参考にし，具体的かつ専門用語の使用を控えた「はいいいえ」で答える 17 項目とした，対象者にはその後高齢者総合機能評価（CGA）を試行し，新予診票の構成概念妥当性およ び因子妥当性を検討した，また，旧/新予診票間での各質問項目の陽性回答率の比較のほか, 新予診票を活 用する際に, 回答者が本人の場合と同伴者の場合とで陽性回答率に違いが見られるかどうかについても併せ て検討した. 結果 : 対象者における予診票の回収率は $100 \%$ であり, 旧/新の予診票回答者の年齢・男女比・ MMSE 得点など基本属性に差は無かった. 新予診票と CGA 各項目との相関を検討したところ, 新予診票 の 17 項目全てがCGA 各項目のいずれかと少なくとも 1 つの有意な相関を有した．また因子分析の結果 17 項目は 8 つ因子に分類され，いずれもCGA 各項目と有意な相関が認められた．信頼性に関しては, Cronbach の $\alpha$ 係数が 0.729 , Guttmann の折半法では係数 0.619 であった. 旧/新予診票ともに, 患者が高齢で MMSE 低值なほど同伴者が回答していた．新予診票において本人の訴えが最も多い項目は「不眠」であり， これは同伴者が記入した場合でも同様の陽性率であった。一方,「つまずき」「転倒」「歩行障害」「妄想」では本 人ょりも同伴者が「あり」と多く回答した.「食欲低下」「尿失禁」は旧予診票では同伴者回答での陽性率が高 かったが, 新予診票では回答者による差が無くなった。旧/新予診票間の比較では, 新予診票での陽性回答 率は不眠については上昇し, 頻尿では低下した。転倒に関しては, 本人の陽性回答率は旧/新予診票で变化 がなかったが, 同伴者の回答では新予診票で陽性回答率が上昇した. 結論 : 新予診票は物忘れ外来の老年症 候群検出のスクリーニングとして十分使用に耐えうる妥当性・信頼性を有すると考えられた．また老年症候 群の把握に対しては, 単に各症候の有無を質問するよりも, 具体的な数字や服薬の有無, その結果困難が生 じているかなどを考慮して質問する必要があると同時に, 高龃者の身体状況の把握には同伴者の視点が重要 であることが示された.

Key words : 老年症候群，予診票，高齢者総合機能評価，妥当性，信頼性

（日老医誌 $2014 ； 51 ： 161-169 ）$

\section{緒 言}

高齢者の診療において，加齢に伴い出現する老年症候 群を適切に評価することは，主病の診断や治療方針決定 の上で重要である．また，日常生活上の困難，すなわち

K. Nagai, H. Koshiba, Y. Kobayashi, Y. Yamada, N. Sudoh, H. Hasegawa, T. Matsui, K. Kozaki : 杏林大学医 学部高齢医学

受付日：2013.7.3, 採用日：2013. 12.25
ADL や QOL の阻害要因把握のためにも重要な課題で ある．予診の役割も患者の主訴や背景因子を聴取するだ けの場ではなく, 高齢者診療においては, キーパーソン から患者の病態につながる重要な情報を得られる場であ り, 高齢者総合機能評価 (Comprehensive Geriatric Assessment : CGA）もこの段階から始まっているといっ

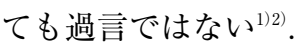

老年症候群は「高齢者に多い，あるいは特有な症状所 見の総称」であり ${ }^{3)}$ ，大内らにより「加齢変化がなく広 
い年代で出現する症候」「前期高齢者で増加する症候」後 期高齢者で増加する症候」の 3 群に分類されること, そ のなかでも「後期高齢者で増加する症候」は在宅維持阻 害要因となることが報告されている4)。この報告をもと に筆者らの施設では老年症候群把握のための外来予診票 を作成した。質問項目は外来受診高齢者に有用と思われ る項目，すなわち「加齢変化がなく広い年代で出現する 症候」の中から「めまい」「不眠」「転倒」を,「前期高齢者 で増加する症候」から「しびれ」「便秘」「食欲低下」を,「後 期高齢者で増加する症候」から「尿失禁」「頻尿」「ん妄」 の項目を採用した ${ }^{55}$. 2003 年に作成して以来もの忘れセ ンター初診時に使用してきたが，この旧予診票を使用し ていく中でいくつかの問題点が浮かびあがってきた.

一つは医療側の要請である。もの忘れセンターでの診 療が経過するにつれ，神経所見や精神徵候を伴う認知症 患者が増えたことや, 認知症患者の予後に影響する ADL や虚弱の程度を予診段階で把握する必要性が高まってき た．多様な認知症患者が診断・治療を求めて来院するよ うになり，例えばレビー小体型認知症では認知障害の程 度は軽くとも幻視, 安静時振戦, 無動といった徵候が病 初期に出現するし ${ }^{6)}$ ，脳血管性認知症では嬹下障害が転 倒とならび重要な ADL や QOL の低下因子となること から ${ }^{7)}$ ，患者および家族が日常生活において捉えられる 徵候を予診段階で拾い上げる必要性が高まったのであ る.

もう一つは記入時の問題である．旧予診票の質問は医 学的症候を「あり/なし」の形で直接問うもので患者に とって具体的な言葉に翻訳されていなかった。そのため 患者や家族が回答する際に判断に窮したのか，無回答の 項目が多く見られた。 また個々の症候の程度や質に関し た質問項目がないために，症候そのものの「あり/なし」 が回答者の主観に帰し，後の集計の際のデータの信頼性 や客観性に瑕疪が生じる恐れがあった。これは個々の症 候に関する質問の評価基準が明確でないためであり，結 果として日常生活を老年医学的な観点から把握する上で も, 集計したデータの客観性や信頼性を担保する上でも, 初診時の老年症候群の存在を適切に評価できていないと 考えられた。

そこで今回我々の施設では，旧予診票の「あり/なし」 の選択という簡便さを残しつつ質問文の内容とレイアウ 卜を変更した新たな予診票を作成し，この新予診票の妥 当性および信頼性を検討した，すなわち，もの忘れセン ターにおいて予診に続いて行っている CGA を補完しう るか否かの検討を行った。 また，旧/新両予診票におけ る各質問項目の陽性回答率の比較のほか, 新予診票を活
用する際に，回答者が本人の場合と同伴者の場合とで陽 性回答率に違いが見られるかどうかについても併せて検 討した.

\section{方 法}

\section{1. 対象}

2011 年 10 月〜 2012 年 12 月に受診した杏林大学医学 部付属病院もの忘れセンターの初診患者 736 名を対象に した．そのうち，(1) 2011 年 10 月〜2012 年 7 月の初診 患者 459 名には旧予診票を配布し, (2) 2012 年 8 月〜2012 年 12 月の初診患者 277 名には新予診票を配布した（表 1).これを本人，もしくは同伴者に記入してもらった. 新予診票を行った全患者はその後臨床心理士による CGA を試行した2). CGA の内訳は基本的 ADLに関し て Barthel index $(\text { BTHL })^{8}$, 手段的 ADL に Lawton \& Brody's IADL (IADL) ${ }^{9}$ を, 認知機能検査に Mini-Mental State Examination (MMSE) を, 精神状態に Geriatric Depression Scale $(\mathrm{GDS})^{10)}$ を, 周辺症状に Dementia Behavior Disturbance Scale（DBD）を(11), 意欲の指標に Vitality Index（VI）を ${ }^{12)}$ ，介護負担にZ Zarit 介護負担尺 度 (Zarit $)^{13}$ を行った。なお，本研究は杏林大学医学部 倫理委員会において承認され, 調査対象者もしくは代諾 者から書面にて同意を得た後に行った。

2. 新予診票の作成（表 1)

新予診票では旧予診票に項目を新たに追加した。旧予 診票では先述の通り 14 項目を選択したが，新たに，安 静時振戦, 無動, 嚥下障害についての質問を追加した。

新予診票では各症候の「あり/なし」を明確にするた めに, 以下に示す各診断基準を参考に質問内容を作成し た「転倒」は鳥羽らが作成した「転倒リスク評価表」を 参考に過去 1 年以内の転倒歴を問うものにし ${ }^{14)}$,「つまず き」も「転倒リスク評価表」の質問文を参考にした。 そ のほか「頻尿」は日本排尿機能学会の「夜間頻尿診療ガ イドライン 」5)の定義から,「1 日 8 回以上の排尿もしくは 夜の排尿回数が 3 回以上」という質問にした。便秘」に ついては「日本消化器病学会ホームページ」上の用語集 を参考に「3 日以上便が出ない, 便秘にまつわる不快感 がある，もしくは下剤を服用している」とした ${ }^{16}$.「不眠」 は「睡眠薬の適正な使用と休薬のための診療ガイドライ ン」をもとにし ${ }^{17}$, 「体重減少」は過去半年に体重の $5 \%$ 以上の減少が病的であることを考慮し,「半年で $2 \mathrm{~kg}$ 以 上の減少のあり/なし」とした ${ }^{18}$.

上記のような診断基準が確立されていない項目につい ては，患者・家族が症候の有無を判断する際に迷いがな いよう，質問文を専門用語から具体的な症状を問う文に 
表 1 旧/新 予診票の質問項目

問. 普段の生活において以下の症状がありますか?

\begin{tabular}{|c|c|}
\hline ○幻覚 & なし / あり \\
\hline 妄想 & なし／あり \\
\hline ○不眠 & なし／あり \\
\hline ○めまい： & なし／あり \\
\hline 麻痺 & なし／あり \\
\hline ○しびれ： & なし／あり \\
\hline 歩行障害： & なし／あり \\
\hline ○つまずき： & なし／あり \\
\hline 転倒 & なし／あり \\
\hline 尿失禁 & なし／あり \\
\hline 頻尿※： & なし／あり \\
\hline 便秘 : & なし／あり \\
\hline 食欲低下： & なし／あり \\
\hline 体重減少： & なし／あり \\
\hline
\end{tabular}

※頻尿は以下の(1)，(2)どちらかを 満たす場合「あり」としてください.

(1) 1 日の排尿回数が 8 回以上, も

しくは(2)夜間排尿回数が 3 回以上 b）新予診票

\begin{tabular}{|c|c|c|}
\hline 目が回る，もしくは，ふわふわする & はい・いいえ & (めまい) \\
\hline 麻痺がある & はい・いいえ & （麻痺） \\
\hline しびれがある & はい・いいえ & （しびれ） \\
\hline 歩くのに不自由がある & はい・いいえ & （歩行障害） \\
\hline 最近よくつまずくようになった & はい・いいえ & （つまずき） \\
\hline 1 年以内に転んだことがある & はい・いいえ & （転倒） \\
\hline 尿が漏れる & はい・いいえ & (尿失禁) \\
\hline $\begin{array}{l}\text { 排尿が頻回で本人もしくは家族が困っている } \\
(1 \text { 日 } 8 \text { 回以上の排尿もしくは夜の排尿回数が } 3 \text { 回以上) }\end{array}$ & はい・いいえ & （頻尿） \\
\hline $\begin{array}{l}3 \text { 日以上便が出ない, 便秘にまつわる不快感がある } \\
\text { もしくは下剬を服用している }\end{array}$ & はい・いいえ & （便秘） \\
\hline 食欲がでない & はい・いいえ & （食欲低下） \\
\hline ここ半年間で $2 \mathrm{Kg}$ 以上体重が減った & はい・いいえ & （体重減少） \\
\hline 何もしていない時に手足が震える & はい・いいえ & (安静時振戦) \\
\hline 動き始めるのに時間がかかる, 動きが遅い & はい・いいえ & （無動） \\
\hline 食事中もしくは食後にむせる & はい・いいえ & （嚥下障害） \\
\hline $\begin{array}{l}\text { 実際にあるるはずのない物や人が見えたり，音や声が聴こえ } \\
\text { たりする }\end{array}$ & はい・いいえ & $($ 幻視 $\cdot$ 幻聴 $)$ \\
\hline 実際にありえないことを主張し, 訂正することができない & はい・いいえ & （妄想） \\
\hline $\begin{array}{l}\text { すぐに寝付けない, 途中で起きてしまう } \\
\text { もしは睡眠薬を服用している }\end{array}$ & はい・いいえ & （不眠） \\
\hline
\end{tabular}

変更した，例えば「妄想」は症候の「あり/なし」を問 うものから,「実際にありえないことを主張し，訂正する ことができない」という症候の具体的症状の「あり/な し」を問うものに変更した，その他「振戦」「無動」はメ ルクマニュアルを参考に平文化し ${ }^{19)}$,「尿失禁」「めまい」 $\lceil$ 歩行障害」「食欲低下」「嚥下障害」「幻視・幻聴」につい ても平易な文章にし,「麻痺」「しびれ」についてはそのま まの表現にとどめた.

3. 新予診票の妥当性・信頼性の検討

新予診票がもの忘れセンター患者における老年症候群 の検査として耐えうる妥当性・信頼性を持つかどうかに ついて, 以下の検証作業を行った.

1）構成概念妥当性の検討 ${ }^{20}$

新予診票は患者およびその家族から見た老年症候群の 有無をある程度包括的に評価していると期待される。し たがって予診後に行ったCGA の各項目との相関を調べ ることで，収束的妥当性（convergent validity）につい て検証を行った。

2）因子妥当性の検討 21$)$

新予診票は 17 項目より構成されているが，この 17 項 目がいくつの要因に分類されるか, また抽出されたその 要因が老年症候群を捉えるものとして適当かどうかの検 討を因子分析により検討した. 更に抽出された因子と CGA との相関を検討した.

\section{3）信頼性の検討 ${ }^{22)}$}

新予診票が内部一貫性に関する信頼性を持っている か, Cronbach の $\alpha$ 係数と Guttmann の折半法による信 頼度係数を算出し，信頼性の検討を行った。

4. 旧/新予診票の陽性回答率

旧予診票 14 項目と新予診票 17 項目について老年症候 群の各項目に対する陽性率を旧/新の 2 群間で比較した. 旧予診票 14 項目全ての症状は新予診票に引き継がれて おり, この 14 項目について症状あり一「はい」と回答 した陽性回答率について検討した。なお予診票は本人あ るいは同伴者のキーパーソンが回答しているため, 回答 者の違いによる予診票各項目の陽性率に関しても比較を 行った.

\section{5. 統計解析}

統計解析は SPSS Statistics 17.0 (SPSS Inc.) を用い た. 構成概念妥当性の検討については，項目間において 単回帰分析を行った. 因子妥当性の検討では, 主因子法・ 斜交回転プロマックス法による因子分析を行い, 因子負 荷量 0.30 を基準に因子の解釈を行った.

信頼性の検討には Cronbach の $\alpha$ 係数と Guttmann の 折半法による信頼度係数を算出し， 0.800 以上を妥当と した. 旧予診票と新予診票の各項目に対する陽性回答率 の比較にはカテゴリー対カテゴリーの解析には $\chi 2$ 乗検 定を, 年齢, BMI, 一人あたりの陽性項目数, MMSE 
表 2 新予診票項目と高齢者総合機能評価項目との相関

\begin{tabular}{|c|c|c|c|c|c|c|c|}
\hline & \multicolumn{7}{|c|}{ 高齢者総合機能評価 } \\
\hline & BTHL & IADL & GDS & MMSE & VI & DBD & Zarit \\
\hline めまい & -0.02 & 0.10 & $0.18 * *$ & $0.13^{*}$ & 0.00 & 0.07 & -0.04 \\
\hline 麻痺 & -0.06 & $-0.12^{*}$ & $0.13^{*}$ & 0.09 & -0.02 & 0.07 & $0.17 * *$ \\
\hline しびれ & -0.09 & 0.01 & $0.29 * *$ & 0.10 & -0.03 & 0.03 & 0.10 \\
\hline 歩行障害 & $-0.40 * *$ & $-0.34 * *$ & $0.15^{*}$ & $-0.18 * *$ & $-0.28 * *$ & $0.26 * *$ & $0.31 * *$ \\
\hline つまずき & $-0.26 * *$ & $-0.17 * *$ & $0.23 * *$ & -0.05 & $-0.19 * *$ & $0.21 * *$ & $0.19 * *$ \\
\hline 転倒 & $-0.28 * *$ & $-0.21 * *$ & $0.13^{*}$ & $-0.13^{*}$ & $-0.20 * *$ & $0.16^{*}$ & $0.18 * *$ \\
\hline 尿失禁 & $-0.37 * *$ & $-0.26 * *$ & 0.11 & -0.08 & $-0.27 * *$ & $0.28 * *$ & $0.26 * *$ \\
\hline 頻尿 & -0.11 & -0.10 & 0.08 & 0.10 & -0.04 & $0.14^{*}$ & $0.16^{*}$ \\
\hline 便秘 & $-0.13^{*}$ & $-0.22 * *$ & 0.08 & -0.07 & -0.08 & 0.03 & 0.04 \\
\hline 食欲低下 & $-0.17 * *$ & -0.09 & $0.13^{*}$ & -0.08 & -0.11 & 0.08 & 0.00 \\
\hline 体重減少 & $-0.14^{*}$ & -0.06 & 0.10 & -0.08 & -0.12 & $0.19 * *$ & 0.11 \\
\hline 安静時振戦 & $-0.19 * *$ & $-0.13^{*}$ & 0.08 & -0.05 & $-0.22 * *$ & $0.19 * *$ & $0.24 * *$ \\
\hline 無動 & $-0.33 * *$ & $-0.37 * *$ & 0.11 & $-0.21 * *$ & $-0.28 * *$ & $0.21 * *$ & $0.26 * *$ \\
\hline 嚥下障害 & $-0.13^{*}$ & -0.09 & 0.11 & 0.03 & -0.09 & 0.10 & 0.09 \\
\hline 幻覚 or 幻視 · 幻聴 & $-0.24 * *$ & $-0.20 * *$ & 0.05 & $-0.22 * *$ & $-0.20 * *$ & 0.11 & 0.08 \\
\hline 妄想 & $-0.34 * *$ & $-0.31 * *$ & -0.12 & $-0.28 * *$ & $-0.24 * *$ & $0.37 * *$ & $0.26 * *$ \\
\hline 不眠 & -0.09 & -0.08 & $0.20 * *$ & 0.07 & -0.09 & 0.10 & 0.06 \\
\hline
\end{tabular}

$*<0.05, * *<0.01$

Fisherの $\mathrm{r}$ の $\mathrm{z}$ 変換にて相関を検討した

といった連続変数については対応のない $\mathrm{t}$ 検定を用いて 比較し, $\mathrm{p}<0.05$ を統計学的有意とした.

なお IADL については満点が男性 5 点, 女性 8 点と 異なるので, 得点率 $(=$ (点数/満点 $) \times 100(\%))$ を算 出し, 検討に用いた.

\section{結果}

\section{1. 対象}

対象者に扔ける予診票の回収率は $100 \%$ であった，旧 予診票使用時と新予診票使用時の対象者について, 初診 時年齢 (新予診票 vs. 旧予診票 : $79.2 \pm 8.1$ 歳 vs. $79.6 \pm 7.5$ 歳, $p=0.43$ ), 男女比 (男性 $\%: 36.1 \%$ vs. $33.6 \%, p=0.48$ ), BMI $\left(21.1 \pm 5.1 \mathrm{~kg} / \mathrm{m}^{2}\right.$ vs. $\left.20.9 \pm 5.6 \mathrm{~kg} / \mathrm{m}^{2}, \mathrm{p}=0.54\right)$, MMSE 得点 $(21.8 \pm 5.8$ 点 vs. $21.8 \pm 5.6$ 点, $\mathrm{p}=0.95)$ に 有意な違いは認められなかった。また，記入者のうち本 人が占める割合（新予診票vs. 旧予診票： $44.0 \% \mathrm{vs}$, $33.4 \%, p=0.25 ） も$ 両予診票で差は認められなかった.

2. 新予診票の妥当性の検討

\section{1）構成概念妥当性の検討}

新予診票の 17 項目と CGA 各項目との相関を検討し たところ, 新予診票項目 17 項目全てが, CGA 各項目の いずれかと有意な相関を有した（表 2)．BTHL の得点 と相関が強い項目は歩行障害(「歩くのに不自由があ る」: $\mathrm{r}=-0.40, \mathrm{p}<0.01 ） て ゙ ，$ IADL の悪化を反映する 項目は無動(「動き始めるのに時間がかかる, 動きが遅
い」: $\mathrm{r}=-0.37, \mathrm{p}<0.01)$ や歩行障害であった. また GDS の悪化と関与する項目はしびれ(「しびれがある」: $\mathrm{r}=$ $0.29, \mathrm{p}<0.01)$ や不眠（「すぐに寝付けない，途中で起き てしまう，もしくは睡眠薬を服用している」 $\mathrm{r}=0.20$, $\mathrm{p}<0.01)$, MMSE 低值は妄想や幻覚 or 幻視・幻聴に関 する項目が，VI とは歩行障害や無動が，DBD は妄想が, Zarit 介護負担度は歩行障害, 尿失禁, 妄想といった質 問項目が有意に関連していた。

2）因子妥当性の検討

新予診票 17 項目について因子分析を行った結果, 17 項目は 8 つ因子に分類された（表 3 )。因子 1 には転 倒・歩行に関する因子が，因子 2 には麻疩・しびれが, 因子 3 には排尿に関する因子が，因子 4 には不眠といっ た項目が分類された。因子 6 における曣下障害は因子負 荷量が 0.256 と低く, 解析上の除外項目に該当した.

次いで，これら抽出された 8 因子について CGA 項目 との相関を調べた(表 4). 因子 1 は CGA のうち BTHL, IADL，VI，Zaritなどと関連が梁く，また年齢とも強 い相関を示したほか, 因子 2 はGDSと, 因子 3 は BTHL, Zarit と, 因子 5 はBMI と, 因子 6 は MMSE, DBD と相関が認められた。

\section{3. 新予診票の信頼性の検討}

内的整合性を求めることで旧/新予診票の信頼性を評 価した，指標である Cronbach の $\alpha$ 係数は，新予診票 17 項目では $\alpha=0.729$, Guttmann の折半法による信頼度倸 
表 3 新予診票の項目に関する因子分析

\begin{tabular}{|c|c|c|c|c|c|c|c|c|}
\hline & \multicolumn{8}{|c|}{ 因子* } \\
\hline & 1 & 2 & 3 & 4 & 5 & 6 & 7 & 8 \\
\hline 歩行障害 & 0.950 & 0.050 & -0.005 & -0.212 & 0.002 & -0.012 & 0.029 & -0.185 \\
\hline 無動 & 0.560 & -0.048 & 0.143 & 0.028 & 0.104 & 0.017 & -0.023 & 0.036 \\
\hline つまずき & 0.548 & -0.090 & -0.021 & 0.109 & -0.087 & 0.029 & 0.226 & 0.192 \\
\hline 転倒 & 0.490 & 0.088 & -0.095 & 0.229 & -0.029 & -0.089 & -0.302 & 0.193 \\
\hline 麻痺 & -0.008 & 0.680 & 0.014 & -0.018 & -0.004 & -0.142 & -0.013 & -0.098 \\
\hline しびれ & 0.022 & 0.512 & -0.002 & -0.091 & 0.044 & 0.015 & 0.185 & 0.210 \\
\hline 尿失禁 & 0.182 & -0.148 & 0.613 & -0.050 & -0.030 & -0.069 & 0.104 & 0.055 \\
\hline 頻尿 & -0.111 & 0.166 & 0.588 & -0.065 & 0.011 & -0.016 & -0.077 & 0.239 \\
\hline 不眠 & -0.066 & -0.056 & -0.079 & 0.685 & -0.048 & -0.050 & 0.209 & 0.091 \\
\hline 体重減少 & 0.020 & 0.018 & -0.035 & -0.094 & 0.646 & 0.010 & 0.034 & 0.045 \\
\hline 食欲低下 & -0.009 & -0.006 & 0.059 & 0.316 & 0.342 & -0.014 & 0.058 & -0.084 \\
\hline 幻覚 or 幻視 · 幻聴 & -0.046 & -0.161 & -0.064 & -0.109 & -0.020 & 0.608 & -0.079 & 0.155 \\
\hline 安静時振戦 & 0.130 & 0.177 & -0.109 & 0.021 & 0.066 & 0.348 & 0.093 & 0.030 \\
\hline 妄想 & 0.054 & -0.060 & 0.039 & 0.121 & 0.143 & 0.337 & -0.082 & -0.045 \\
\hline 臙下障害 & 0.023 & 0.183 & 0.131 & 0.143 & -0.196 & 0.256 & 0.013 & -0.157 \\
\hline めまい & 0.014 & 0.066 & 0.015 & 0.228 & 0.042 & -0.085 & 0.593 & -0.059 \\
\hline 便秘 & -0.008 & -0.015 & 0.197 & 0.078 & 0.015 & 0.111 & -0.047 & 0.539 \\
\hline
\end{tabular}

因子抽出法：主因子法 回転法：Kaiser の正規化を伴うプロマックス法

*16 回の反復で回転が収束

表 4 抽出された因子項目と高齢者総合機能評価項目との相関

\begin{tabular}{|c|c|c|c|c|c|c|c|c|c|}
\hline \multirow{2}{*}{ 回帰係数 } & \multirow{2}{*}{ 年齢 } & \multirow{2}{*}{ BMI } & \multicolumn{7}{|c|}{ 高齢者総合機能評価項目 } \\
\hline & & & BTHL & IADL\% & MMSE & GDS & DBD & VI & Zarit \\
\hline $\begin{array}{l}\text { 因子 } 1 \\
(\text { 歩行・無動・つまずき・転倒 })\end{array}$ & $0.29 * *$ & 0.03 & $-0.43^{* *}$ & $-0.37 * *$ & $-0.19 * *$ & $0.21 * *$ & $0.28 * *$ & $-0.32 * *$ & $0.32 * *$ \\
\hline 因子 2（麻痷・しびれ） & 0.03 & -0.01 & $-0.08 *$ & -0.04 & 0.10 & $0.26 * *$ & 0.05 & -0.02 & $0.14^{*}$ \\
\hline 因子 3（尿失禁 · 頻尿 $)$ & $0.18 * *$ & 0.04 & $-0.30 * *$ & $-0.22 * *$ & 0.01 & 0.11 & $0.26 * *$ & $-0.20 * *$ & $0.27 * *$ \\
\hline 因子 4（不眠） & 0.13 & -0.02 & -0.09 & -0.08 & 0.07 & $0.20 * *$ & 0.10 & -0.09 & 0.06 \\
\hline 因子 5（体重低下·食欲減少） & 0.11 & $-0.23 * *$ & $-0.16 * *$ & -0.11 & -0.09 & $0.14^{*}$ & $0.16^{*}$ & $-0.13^{*}$ & 0.05 \\
\hline 因子 6（幻覚·振戦・妄想） & 0.11 & -0.02 & $-0.36 * *$ & $-0.32 * *$ & $-0.30 * *$ & -0.02 & $0.33^{* *}$ & $-0.30 * *$ & $0.26 * *$ \\
\hline 因子 7 (めまい) & -0.08 & 0.04 & -0.02 & 0.11 & $0.14^{*}$ & $0.18 * *$ & 0.06 & 0.00 & -0.05 \\
\hline 因子 8（便秘） & $0.19 * *$ & -0.02 & $-0.13^{*}$ & $-0.22 * *$ & -0.06 & 0.08 & 0.02 & -0.08 & 0.04 \\
\hline
\end{tabular}

$*<0.05, * *<0.01$

数は 0.619 であった.

4. 旧/新予診票における各項目の陽性回答率の比較

1）予診票の記入者による陽性回答率の相違

旧/新予診票ともに，同伴者が回答した場合の方が有 意に患者は高齢で，MMSE 低值であった（表 5)，項目 に「あり」と答える陽性項目数も同伴者が回答するケー スで多く，同伴者が回答した場合，旧/新予診票のいず れでも保有する症候数が約 1.5 項目多かった.

症候ごとに見ると，本人の訴えとして一番陽性率の多 い項目は新予診票では「不眠」であり $39.7 \%$ にのほっっ た．不眠に関しては同伴者が記入した場合でも同様の陽 性率であり両者に差異はみとめられなかった。一方,「っ
まずき」「転倒」「歩行障害」妄想」では本人からの訴えよ りも同伴者が「あり」と回答する割合が多く，この傾向 は旧予診票でも同様であった，特に,「妄想」では本人よ り同伴者は 4 倍以上の高率で「あり」と答えていた。一 方「食欲低下」,「尿失禁」は旧予診票では同伴者回答で の陽性率が高かったが, 新予診票では両者の陽性率の差 が縮まり，有意差が認められなかった．

2）旧予診票/新予診票の間での陽性回答率の相違

不眠に関しては，本人が答えた場合と同伴者が答えた 場合のどちらにおいても新予診票での陽性回答率が上昇 した（表 5)。一方，頻尿の項目は新予診票で本人・同 伴者両者での陽性回答率が低下した．また統計学上有意 
表 5 新/旧予診票各項目の陽性回答率

\begin{tabular}{|c|c|c|c|c|c|c|c|c|}
\hline & \multicolumn{6}{|c|}{ 予診票記入者 (本人 vs. 同伴者) による比較 } & \multirow{2}{*}{\multicolumn{2}{|c|}{$\begin{array}{l}\text { 新予診票 vs. 旧予診票 } \\
\text { での比較（p 值） }\end{array}$}} \\
\hline & \multicolumn{3}{|c|}{ 新予診票 } & \multicolumn{3}{|c|}{ 旧予診票 } & & \\
\hline & 本人回答 & 同伴者回答 & $\mathrm{p}$ 值 & 本人回答 & 同伴者回答 & $\mathrm{p}$ 值 & 本人回答 & 同伴者回答 \\
\hline 人数 & 121 & 154 & & 186 & 268 & & & \\
\hline 年齢 & $76 \pm 9.7$ & $81.6 \pm 5.5$ & $<0.01$ & $76.8 \pm 8.0$ & $81.7 \pm 6.4$ & $<0.01$ & 0.51 & 0.89 \\
\hline 男性，％ & 46.3 & 28.6 & $<0.01$ & 38.1 & 29.9 & 0.06 & 0.25 & 0.78 \\
\hline MMSE & $24.8 \pm 4.2$ & $19.4 \pm 5.8$ & $<0.01$ & $24.9 \pm 3.9$ & $19.5 \pm 5.5$ & $<0.01$ & 0.71 & 0.89 \\
\hline BMI & $21.6 \pm 5.1$ & $20.8 \pm 5.1$ & 0.19 & $21.2 \pm 5.1$ & $20.7 \pm 5.8$ & 0.32 & 0.52 & 0.86 \\
\hline 予診票 & & & & & & & & \\
\hline $\begin{array}{c}\text { 陽性項目数* } \\
\text { 症候の保有率（\%) }\end{array}$ & $3.0 \pm 2.3$ & $4.5 \pm 2.8$ & $<0.01$ & $2.9 \pm 2.3$ & $4.3 \pm 2.7$ & $<0.01$ & 0.55 & 0.35 \\
\hline 不眠 & 39.7 & 42.2 & 0.68 & 27.3 & 30.3 & 0.50 & 0.02 & 0.01 \\
\hline つまずき & 31.9 & 45.4 & 0.02 & 39.7 & 51.5 & 0.01 & 0.20 & 0.23 \\
\hline めまい & 28.1 & 23.5 & 0.39 & 21.2 & 18.8 & 0.53 & 0.15 & 0.25 \\
\hline 尿失禁 & 26.7 & 36.8 & 0.07 & 21.4 & 40.1 & $<0.01$ & 0.22 & 0.51 \\
\hline 体重減少 & 25.6 & 34.7 & 0.11 & 22.8 & 29.7 & 0.11 & 0.36 & 0.30 \\
\hline 頻尿 & 24.0 & 32.7 & 0.11 & 36.8 & 47.8 & 0.02 & 0.02 & 0.00 \\
\hline 便秘 & 24.0 & 32.7 & 0.11 & 31.7 & 29.4 & 0.60 & 0.13 & 0.48 \\
\hline 転倒 & 23.1 & 49.0 & $<0.01$ & 19.7 & 34.4 & $<0.01$ & 0.36 & 0.00 \\
\hline 歩行障害 & 20.0 & 51.0 & $<0.01$ & 21.0 & 48.5 & $<0.01$ & 0.68 & 0.63 \\
\hline しびれ & 20.0 & 23.0 & 0.55 & 27.5 & 25.3 & 0.60 & 0.20 & 0.61 \\
\hline 食欲低下 & 15.1 & 21.3 & 0.19 & 14.3 & 26.5 & $<0.01$ & 0.83 & 0.24 \\
\hline 幻覚/幻視 $\cdot$ 幻聴 † & 10.7 & 19.1 & 0.06 & 4.3 & 16.5 & $<0.01$ & 0.02 & 0.50 \\
\hline 麻痺 & 7.6 & 8.6 & 0.77 & 2.7 & 8.7 & 0.01 & 0.05 & 0.96 \\
\hline 妄想 & 5.8 & 37.9 & $<0.01$ & 6.1 & 28.2 & $<0.01$ & 0.83 & 0.04 \\
\hline 無動 & 31.4 & 64.1 & $<0.01$ & - & - & - & - & - \\
\hline 嚥下障害 & 16.7 & 25.7 & 0.07 & - & - & - & - & - \\
\hline 安静時振戦 & 5.0 & 13.2 & 0.02 & - & - & - & - & - \\
\hline
\end{tabular}

* 新/旧予診票で共通する 14 項目について「あり」と回答した数

†旧質問表では「幻覚 あり/なし」で，新質問表では「幻視・幻聴」として質問している

ではなかったが,「幻視・幻聴」の項目で本人が「あり」 と答える割合が旧予診票の $4.3 \%$ から新予診票では $10.7 \%$ と 2 倍以上に上昇した．転倒に関しては，本人の 陽性率は旧/新予診票で変化がなかったが, 同伴者の回 答では新予診票で多く陽性の回答が得られた.

\section{考察}

高齢者の慢性疾患の集合体である老年症候群の評価方 法については，鳥羽らがまとめているように，種々の評 価スケールや臨床検査を用いて個々の症候を詳細に検査 することができる233. ᄂかしすべての検查を実施するこ とは現害的には不可能であり，実際には担当医は患者の 持つ症状に優先順位をつけ検査を行い治療にあたること になる，その一方で，老年症候群を有する高齢者を生活 機能，精神機能，社会・環境面から包括的に捉えるのが CGA の本質であり, 評価の結果, 多職種連携のマネー ジメントという ‘治療”を以って高齢者の予後や QOL
改善を図る ${ }^{2324)}$.

予診の一般的な目的は患者の主訴に直接関係する，あ るいは背景にある症候をあぶりだすことにあるが，もの 忘れセンター予診票は，高齢者が健康に生活する上で基 本的な要素である運動・感覚・食事・排泄・睡眠・精神 活動において問題があるかどうか明らかにすることを目 的としている ${ }^{25)}$. 今回我々が行った新予診票の因子分析 (表 3)，およびCGA との関連の検討（表 4）において, 予診票および予診票項目から抽出された各因子は，それ ぞれCGA 結果と有意に関連しており，もの忘れセン ター予診票としての有用性が示されたものと考えられ る.

まず構成概念妥当性の検討では, 予診票のすべての項 目はCGA と有意な相関を有していた。例えば,「歩行」 「つまずき」「転倒」「無動」といった項目で「ある」と答 えると ADL 低下がうかがわれ,「妄想」が「ある」場合 には, 認知機能低下に伴う周辺症状が出現したり, 介護 
負担が増大したりすることが示唆された ${ }^{26)}$ (表 2$)$. 反対 にCGAの各項目もまた複数の新予診票項目と関連があ り, BTHLは 17 項目中 12 項目と関連が認められた. 一方 MMSE は 6 項目との関連にとどまり，相関係数も 総じて低值であった。これは新予診票には直接認知機低 下の有無を直接問う質問がないことから予測されるが, 本予診票に弁別的妥当性があることが示されたと言え る.

次いで行った因子分析によって新予診票 17 項目は 8 つの因子に分類された．各因子をみると，因子 1 は「歩 行障害」「無動」「つまずき」「転倒」からなり，“運動機能” を反映しているであろうこと，因子 $2\lceil$ 麻瘏」「しびれ」 は感覚機能を, 因子 3,8 では排泄機能を, 因子 4 は睡 眠障害を, 因子 5 は摂食機能を, 因子 6 は精神機能異常, すなわち ‘認知機能低下に伴う周辺症状” あるいは ‘ ビー小体型認知症などの非アルツハイマー型認知症の随 伴症状”を反映するであろうことが示唆された.

また，因子分析の結果抽出された 8 因子は CGA の各 項目と有意に関連していた (表 4). 因子 1一 “運動機能” は ADL 低下のみならず今回調查した CGA 項目すべて の悪化因子となっており，因子 2 の「麻痺」「しびれ」一 “感覚機能’ の項目は因子 7 のめまい」と並び, ADL 低下よりもむしろ GDS 悪化の要因となっていること， 因子 3- “排尿障害” は ADL 悪化因子に加え, 介護負 担や周辺症状に関与することがわかった。一方，もう一 つの排泄機能を反映する「便秘」は介護負担にはならず IADL，つまり患者本人の生活面に関与していた。この ように新予診票は老年症候群と CGA をつなぐ有用な調 查手段であると考えられた。

ところで, 今回新予診票項目の中で「嚥下障害」は CGA 項目の中で BTHL 低下と弱い相関があったものの（表 2)，因子分析では有用な因子として抽出されず，今回の 予診票の中では除外項目として分類された。嚥下障害自 体は高齢とともに増え ${ }^{4}$, 経口摄取の維持や誤嶼性肺炎 に関与する重要な病態であるため症候の拾い上げは必要 である．今回設定した「食事中もしくは食後にむせる」 という質問文では症候を捉えられないのか，予診票では なく誤嚥性肺炎の既往や実際の診察，また嚥下テストの ような客観的評価を用いて評価すべき項目なのか ${ }^{277}$, 新 予診票での例数を増やして更に検討する必要がある.

信頼性に関しては，設定した信頼度係数 0.800 を上回 ることはなかったが, Cronbachの $\alpha$ 係数および Guttmannの折半法による信頼度係数は 0.6 から 0.8 の 間にあり，同一者に繰り返し聴取をし変化を評価する尺 度として最適とは言えないものの, 診察前のスクリーニ
ング使用には差し支えがない程度の信頼性を持つと考え られた222．信頼度を上げるためには質問項目を増やすこ とや，評価をはい/いいえではなく尺度を細かくするな どの必要があるが，その場合スクリーニング評価として の簡便さという利点を失うことが懸念される.

今回の検討では項目の評価に加え, 新/旧予診票にお ける記入者の違いによる回答状況の相違についても検討 した．新予診票に具体的な数字を記載した「頻尿」の項 目は回答者による陽性率の差が無くなった。これは新予 診票において具体的な判断材料を提示したことの有効性 が示されたと考えられる。しかし他の症候では全般的に 同伴者が回答した場合の方が陽性回答率は高く, また, 一人あたりの有する症候の数も有意に多かった（表 5). つまり同伴者が回答する場合の方が症候をより多く，あ るいは厳しく拾い上げているように思われた。ただし本 人が予診票に回答している群では，同伴者が回答してい る場合に比べて平均年齢は若く, MMSE 得点も高いな ど対象者の背景に差異があったことも, 同伴者が回答し ている場合に陽性回答率が多かった理由の一つであろ $j^{28)}$. 本来ならば回答者による差異, すなわち本人回答 分と同伴者回答分との回答状況を比較するために対象者 背景を揃えるべきであった。 しかし今回の検討はもの忘 れ外来の初診患者から連続的に採取したデー夕であり, そのような背景設定ができなかったのは本研究の限界点 である，また背景疾患により，症候によっては本人が予 診票に的確に回答できないこともありうる．特に「妄想」 の項目では本人が「ない」と回答してもその信頼性は低 いと考えられ，このような項目には同伴者の判断が重要 となる，つまり，老年症候群の把握には，同伴者の視点 も重要であることが改めて明らかになった。

今後の課題としては, 本予診票を患者本人と同伴者と の両者に施行し, 本人の訴えと家族の訴えとの相違が介 護負担や患者の治療方針決定に供するかどうかを検討す る予定である，たとえば「幻視・幻聴」では，本人が困っ ている幻視と家族が困る幻視では背景疾患や治療方針が 大きく異なる可能性がある29).

筆者らの施設ではこの初診時予診票のほか, 高齢者総 合機能評価, 画像診断結果などをデータベース管理して いる。 これらの情報の信頼性を高め効率的に利用するこ とで, 高齢者の日常生活全般をより具体的にとらえ, 近 年注目されている虚弱との関連や実診療に活かしていき たい ${ }^{30)}$.

本研究は厚生労働科学研究費補助金・認知症対策総合 研究事業「病・診・介護の連携による認知症ケアネット ワーク構築に関する研究事業」ならびに長寿科学総合研 
究事業「高齢者の薬物治療の安全性に関する研究」の助 成のもと遂行された研究であり,ここに謝意を表します. なお本論文に関して, 開示すべき利益相反状態は存在 しない.

\section{文献}

1) Beck P: The Elderly Patient, In: Clinical Methods: The History, Physical, and Laboratory Examinations 3rd edition, Walker H, Hall W, Hurst J (eds), 2011/01/21 ed, Butterworths, Boston, 1990.

2）鳥羽研二：高齢者総合的機能評価ガイドライン，厚生科 学研究所, 東京, 2003 .

3）鳥羽研二：高齢者に特有な症状一老年症候群。老年医学 テキスト改訂第 3 版（日本老年医学会編）、メジカル ビュー社, 東京, 2011, p66-71.

4）大内尉義, 鳥羽研二：高齗者の新しい総合的機能評価方 法の開発とその応用. 日老医誌 2000; 37: 469-471.

5) Sonohara K, Kozaki K, Akishita M, Nagai K, Hasegawa $\mathrm{H}$, Kuzuya M, et al.: White matter lesions as a feature of cognitive impairment, low vitality and other symptoms of geriatric syndrome in the elderly. Geriatr Gerontol Int 2008; 8: 93-100

6) 藤城弘樹，千葉悠平，井関栄三：認知症臨床に役立つ生 物学的精神医学 (No. 14) レビー小体型認知症の分類 · 病期と診断. 老年精神医学雑誌 2011; 22: 1297-1307.

7）松井敏史, 荒井啓行, 佐々木英忠：高齢者の主要な疾患 の診療と管理の実際 高齢者診療のポイントとコツア ルッハイマー病と血管性痴呆 わが国の 2 大痴呆性疾患 への対応. Medical Practice 2002; 19: 199-208.

8) Mahoney FI, Barthel DW: Functional Evaluation: The Barthel Index. Md State Med J 1965; 14: 61-65.

9) Lawton MP, Brody EM: Assessment of older people: selfmaintaining and instrumental activities of daily living. Gerontologist 1969; 9: 179-186.

10) Sheikh JI, Yesavage JA: Geriatric Depression Scale (GDS): recent evidence and development of a shorter version. Clin Gerontol 1986; 5: 165-173.

11) Baumgarten M, Becker R, Gauthier S: Validity and reliability of the dementia behavior disturbance scale. J Am Geriatr Soc 1990; 38: 221-226.

12) Toba $K$, Nakai R, Akishita M, Iijima S, Nishinaga $M$, Mizoguchi T, et al.: Vitality Index as a useful tool to assess elderly with dementia. Ceriatr Gerontol Int 2002; 2: 23-29.

13) Hirono N, Kobayashi H, Mori E: [Caregiver burden in dementia: evaluation with a Japanese version of the Zarit caregiver burden interview]. No To Shinkei 1998; 50: 561-567.

14）鳥羽研二, 大河内二郎, 高橋 泰, 松林公蔵, 西永正典,
山田思鶴ほか：転倒ハイリスク者の早期発見の評価方法 作成ワーキンググループ：転倒リスク予測のための「転 倒スコア」の開発と妥当性の検証. 日老医誌 2005; 42: 346-352.

15）夜間頻尿診療ガイドライン作成委員会：夜間頻尿診療ガ イドライン, Blackwell Publishing, 東京, 2009.

16）便秘. 医学用語集，日本消化器病学会 2013 [cited 2013; Available from: http://www.jsge.or.jp/cgi-bin/yohgo/in dex.cgi?type $=50$ on $\& \mathrm{pk}=\mathrm{D} 57$

17）三島和夫編：睡眠薬の適正な使用と休薬のための診療ガ イドライン，国立精神神経センター，東京，2013.

18) Bales CW, Ritchie CS: Sarcopenia, weight loss, and nutritional frailty in the elderly. Annu Rev Nutr 2002; 22: 309323.

19） Beers MH：メルクマニュアル，第 18 版 日本語版，日 経 BP 社，東京，2006.

20) Streiner DL, Norman GR: Health Mesurement Scales-a practical guide to their development and use, Oxford University Press, New York, 1991.

21) Menkov GY, Morrin M, Ward A, Schwartz B, Hulland J: A Short Form of the Maximization Scale: Factor Structure, Reliability and Validity Studies. Judgment and Decision Making 2008; 3: 371-388.

22）奥田 裕, 荻野禎子, 小澤佑介, 原田慎一, 江連亜弥, 内山 靖: 臨床的体幹機能検査 (FACT) の開発と信頼 性. 理学療法科学 2006; 21:357-362.

23）神崎恒一：高齢者の総合機能評価と多職種連携. 日老医 誌 2012; 49: 569-572.

24) Rubenstein LZ, Josephson KR, Wieland GD, English PA, Sayre JA, Kane RL: Effectiveness of a geriatric evaluation unit. A randomized clinical trial. N Engl J Med 1984; 311: 1664-1670.

25) Elsawy B, Higgins KE: The geriatric assessment. Am Fam Physician 2011; 83: 48-56.

26) Tanji H, Ootsuki M, Matsui T, Maruyama M, Nemoto M, Tomita N, et al.: Dementia caregivers' burdens and use of public services. Geriatr Gerontol Int 2005; 5: 94-98.

27）馬場 幸, 寺本信嗣, 長谷川浩, 町田綾子, 秋下雅弘, 鳥羽研二：痴呆高齢者に対する䁵下障害のスクリーニン グ方法の検討 簡易嚥下誘発試験と反復唾液舆下テスト の比較. 日老医誌 2005; 42: 323-327.

28) Crum RM, Anthony JC, Bassett SS, Folstein MF: Population-based norms for the Mini-Mental State Examination by age and educational level. Jama 1993; 269: 2386-2391.

29) Korner A, Lopez AG, Lauritzen L, Andersen PK, Kessing LV: Acute and transient psychosis in old age and the subsequent risk of dementia: a nationwide register-based study. Geriatr Gerontol Int 2009; 9: 62-68.

30）神崎恒一：介護予防 現状・課題と新たな方向性 虚弱 の概念と転倒予防。 日老医誌 2012; 49: 58-59. 


\title{
Development and usefulness of a new questionnaire for assessing geriatric syndrome
}

\author{
Kumiko Nagai, Hitomi Koshiba, Yoshio Kobayashi, Yukiko Yamada, Noriko Sudoh, Hiroshi Hasegawa, \\ Toshifumi Matsui and Koichi Kozaki
}

\begin{abstract}
Aim: To assess the validity and reliability of a pre-visit questionnaire newly developed to identify geriatric conditions in older adults in an outpatient clinical setting.

Methods: A new self-administered questionnaire consisting of 17 items was distributed to 277 patients or their caregivers visiting a memory clinic. The questionnaire was designed to address common symptoms associated with an increasing age based on yes/no responses with symptom-oriented questions avoiding the use of 'jargon'. The patients also underwent comprehensive geriatric assessments (CGAs), as well as tests of the Barthel index, Lawton instrumental activities of daily living, mini-mental state examination (MMSE), geriatric depression scale and vitality index to assess construct validity in a factor analysis. The differences in the prevalence of symptoms between the patients and their caregivers were also assessed.

Results: The factor analysis detected eight components that included symptoms referring to gait disturbance, numbness, urinary incontinence, insomnia or body weight loss and were significantly correlated with the measurements of the CGA. Cronbach's alpha coefficient for the internal consistency of the questionnaire was 0.729 . The caregivers tended to respond to the questionnaire for older patients $(81.6 \pm 5.5$ vs. $76 \pm 9.7$ years of age for patients with caregivers as responders versus patients as responders respectively, $\mathrm{p}<0.001)$ and those with lower MMSE scores $(19.4 \pm 5.8$ vs. $24.8 \pm 4.2 \mathrm{points}, \mathrm{p}<0.001)$. A higher prevalence of falls and episodes of delusions was observed among the patients with caregivers as responders.

Conclusions: These results demonstrate that the current questionnaire is a valid and reliable instrument for use in clinical practice and that obtaining collateral source information is essential for assessing significant geriatric symptoms. Such information also provides clinicians with a guide to conducting more detailed evaluations of geriatric conditions and aids in the diagnostic process in older patients with multidisciplinary complications.
\end{abstract}

Key words: Geriatric syndrome, Questionnaire, Comprehensive geriatric assessment (CGA), Validity, Reliability

(Nippon Ronen Igakkai Zasshi 2014; 51: 161-169)

Department of Geriatric Medicine, Kyorin University School of Medicine 